\title{
The effects of prepartum energy intake and peripartum rumen-protected choline supplementation on hepatic genes involved in glucose and lipid metabolism
}

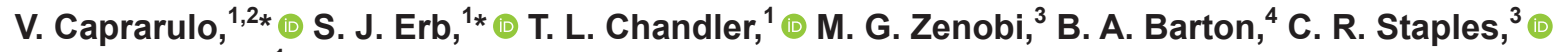 \\ and H. M. White ${ }^{1} \dagger$ (i) \\ ${ }^{1}$ Department of Dairy Science, University of Wisconsin-Madison, Madison 53706 \\ ${ }^{2}$ Department of Health, Animal Science and Food Safety, University of Milan, Milan 20134, Italy \\ ${ }^{3}$ Department of Animal Sciences, University of Florida, Gainesville 32611 \\ ${ }^{4}$ Balchem Corp., New Hampton, NY 10958
}

\section{ABSTRACT}

Nutritional interventions, either by controlling dietary energy (DE) or supplementing rumen-protected choline (RPC) or both, may mitigate negative postpartum metabolic health outcomes. A companion paper previously reported the effects of DE density and RPC supplementation on production and health outcomes. The objective of this study was to examine the effects of DE and RPC supplementation on the expression of hepatic oxidative, gluconeogenic, and lipid transport genes during the periparturient period. At $47 \pm 6 \mathrm{~d}$ relative to calving (DRTC), 93 multiparous Holstein cows were randomly assigned in groups to dietary treatments in a $2 \times 2$ factorial of (1) excess energy (EXE) without RPC supplementation (1.63 Mcal of $\mathrm{NE}_{\mathrm{L}} / \mathrm{kg}$ of dry matter; EXE-RPC); (2) maintenance energy (MNE) without RPC supplementation (1.40 Mcal of $\mathrm{NE}_{\mathrm{L}} / \mathrm{kg}$ dry matter; MNE-RPC); (3) EXE with RPC supplementation (EXE+RPC); and (4) MNE with RPC supplementation (MNE+RPC). To achieve the objective of this research, liver biopsy samples were collected at $-14,+7,+14$, and +21 DRTC and analyzed for mRNA expression $(\mathrm{n}=16 /$ treatment $)$. The interaction of $\mathrm{DE} \times \mathrm{RPC}$ decreased glucose-6-phosphatase and increased peroxisome proliferator-activated receptor $\alpha$ in MNE+RPC cows. Expression of cytosolic phosphoenolpyruvate carboxykinase was altered by the interaction of dietary treatments with reduced expression in $\mathrm{EXE}+\mathrm{RPC}$ cows. A dietary treatment interaction was detected for expression of pyruvate carboxylase although means were not separated. Dietary treatment interactions did not alter expression of carnitine palmitoyltransferase $1 \mathrm{~A}$ or microsomal triglyceride transfer

Received May 4, 2020.

Accepted August 7, 2020.

*These authors contributed equally to this work.

†Corresponding author: heather.white@wisc.edu protein. The 3-way interaction of $\mathrm{DE} \times \mathrm{RPC} \times \mathrm{DRTC}$ affected expression of carnitine palmitoyltransferase 1A, glucose-6-phosphatase, and peroxisome proliferator-activated receptor $\alpha$ and tended to affect cytosolic phosphoenolpyruvate carboxykinase. Despite previously reported independent effects of DE and RPC on production variables, treatments interacted to influence hepatic metabolism through altered gene expression.

Key words: choline, energy, gluconeogenesis, tricarboxylic acid (TCA) cycle

\section{INTRODUCTION}

The periparturient period is a metabolically challenging period for dairy cows because homeorhetic changes, negative energy balance, and increased risk for metabolic disorders can negatively affect dairy cattle health and productivity (Grummer, 1995; Drackley, 1999; White, 2015). Insufficient feed intake combined with high energy requirements for lactation often result in negative energy balance (Block et al., 2001; Drackley et al., 2001; Grummer et al., 2004). In response, triglycerides (TG) are mobilized from adipose tissue, yielding fatty acids (FA) and glycerol, which can provide energy and glucose precursors, respectively (Dole, 1956; Gordon and Cherkes, 1956). The resulting increase in circulating FA and influx to the liver can predispose cows to hepatic lipidosis and ketosis (Grummer, 1993; White, 2015).

To prevent hepatic lipidosis, common practices are to control BCS loss (Janovick et al., 2011) across the transition to lactation period, feed prepartum diets with decreased dietary energy (DE) density, and supplement nutrients that promote liver function such as choline (Overton and Piepenbrink, 1999; Arshad et al., 2020; McFadden et al., 2020). Overfeeding DE prepartum to nonlactating cows results in higher conditioned cows, as surplus energy is stored in adipose depots (Drackley et al., 2014; Contreras et al., 2017), and causes high 
rates of lipid mobilization, resulting in greater plasma FA and BHB (Janovick et al., 2011; Mann et al., 2015) and liver TG accumulation postpartum (Janovick et al., 2011; Graugnard et al., 2013). Controlling prepartum DE has resulted in improved postpartum health with maintained milk production (Graugnard et al., 2013; Mann et al., 2015). Alternatively, nutrients such as rumen-protected choline (RPC) are supplemented during the transition period, and research suggests that RPC supplementation decreases FA accumulation in the liver in a dose-responsive manner (Zenobi et al., 2018b) and increases milk and ECM production (Arshad et al., 2020; McFadden et al., 2020).

Given the role of these peripartum interventions to influence production and hepatic health, in vivo and in vitro research has explored the influence of the interventions on hepatic metabolism. Both peripartum RPC supplementation and controlled prepartum energy have been demonstrated to alter aspects of hepatic gluconeogenesis [glucose-6-phosphatase $(G 6 P C)$, pyruvate carboxylase $(P C)$, cytosolic phosphoenolpyruvate carboxykinase $(P C K 1)]$ or lipid metabolism [carnitine palmitoyltransferase 1A (CPT1A), microsomal TG transfer protein $(M T T P)$, peroxisome proliferator-activated receptor $\alpha(P P A R A)$ ] (Khan et al., 2014; Huang et al., 2019; McFadden et al., 2020), and support of hepatic glucose and lipid metabolism is thought to be part of the mechanism for production and health responses associated with these peripartum interventions. Although both controlling prepartum energy and supplementing RPC have demonstrated positive impacts on postpartum metabolic health, it is unknown whether the mechanisms are independent, given the lack of factorial designed experiments. Therefore, the objective of this collaborative project was to examine the effects and potential interactions of prepartum DE and peripartum RPC supplementation on postpartum production, metabolic health, and gene expression of enzymes that influence hepatic metabolism. A companion paper reported production and health outcomes (Zenobi et al., 2018a) and a related paper reported immune responses (Zenobi et al., 2020). The objective of this analysis was to determine effects of prepartum controlled DE and peripartum supplementation of RPC on expression of hepatic genes involved in gluconeogenesis, FA oxidation, and lipid metabolism.

\section{MATERIALS AND METHODS}

This experiment was conducted in collaboration with the University of Florida (Gainesville, FL). All experimental procedures involving animals were conducted at the University of Florida and were approved by the University of Florida Animal Care and Use Commit- tee. Pregnant nonlactating multiparous Holstein cows ( $\mathrm{n}=93$ ) were grouped by expected calving date and randomly assigned at $47 \pm 6 \mathrm{~d}$ before the expected calving date to 1 of 4 treatment groups in a $2 \times 2$ factorial design of either (1) excess energy (EXE) without RPC supplementation (1.63 Mcal of $\mathrm{NE}_{\mathrm{L}} / \mathrm{kg}$ of DM; EXE-RPC); (2) maintenance energy (MNE) without RPC supplementation (1.40 Mcal of $\mathrm{NE}_{\mathrm{L}} / \mathrm{kg}$ of DM; MNE-RPC); (3) EXE with RPC supplementation (EXE+RPC); or (4) MNE with RPC supplementation (MNE+RPC). Supplementation of choline was by once-daily top-dress of $17.3 \mathrm{~g} / \mathrm{d}$ of choline chloride via $60 \mathrm{~g} / \mathrm{d}$ RPC (ReaShure, Balchem Corp., New Hampton, NY) from -21 through $+21 \mathrm{~d}$ relative to calving (DRTC). Diets were provided ad libitum as a TMR using individual feeding gates (Calan Broadbent feeding system, American Calan Inc., Northwood, NH). Detailed methodology, BW, and BCS data, as well as composition and chemical analysis of the diets, have been analyzed and reported previously (Zenobi et al., 2018a).

\section{Liver Tissue Collection and Selection of Cows for Gene Transcript Analysis}

Liver tissue was collected -14 (actual d $11.6 \pm 4.3$ d) $,+7,+14$, and +21 DRTC and then aliquoted and stored at $-80^{\circ} \mathrm{C}$ until analysis, as described previously (Zenobi et al., 2018a). A subset of cows from each treatment group $(\mathrm{n}=16)$ was selected for gene expression analysis, which was done at the University of Wisconsin-Madison. Selection criteria included availability of liver tissue from all 4 biopsy time points, a prepartum biopsy sample at least $5 \mathrm{~d}$ before calving (i.e., cows did not calve more than $10 \mathrm{~d}$ early), and no chronic health conditions that would result in severe reductions in DMI. Given that selection of cows for the gene expression subset $(\mathrm{n}=64)$ was not completely random, key performance variables (DMI, BW, BCS, and DMI as \% of BW), metabolite concentrations (BHB, FA, glucose), and hepatic TG content $(\mu \mathrm{g} / \mu \mathrm{g}$ of DNA) were statistically reanalyzed for the subset to ensure minimal to no differences between the original cohort and subset were found. Analysis for the subset of cows was done for the 0 - to 15-wk period, consistent with the companion paper, and for the 0 - to 3 -wk period of relevance to the period of liver biopsies.

\section{RNA Extraction, Real-Time Quantitative PCR, and Primer Evaluation}

Total RNA $(\mathrm{n}=64)$ was isolated from about 300 mg of liver tissue using Trizol reagent (Invitrogen, 
Carlsbad, CA) by phase separation (Chomczynski, 1993) following the manufacturer's instructions. To eliminate potential DNA contamination, isolated RNA was treated with DNase I and further purified using a RNeasy Mini Kit (Qiagen, Thousand Oaks, CA). Samples were quantified and quality assured (ratios absorbance of 260/280 nm were between 1.9 and 2.1) using a Synergy Hybrid Spectrophotometer (BioTek, Winooski, VT). A concentration of $0.5 \mu \mathrm{g}$ of purified RNA was reverse transcribed using iScript Reverse Transcriptase Supermix (Bio-Rad Laboratories Inc., Hercules, CA) in a C1000 Touch ThermoCycler (BioRad Laboratories). Genes of interest were quantified in a CFX-384 Real-Time System (Bio-Rad Laboratories) via real-time quantitative PCR with SsoFast EvaGreen Supermix (Bio-Rad Laboratories) and primers for each gene (Table 1). An RNA pool was formed by combining equal quantities of RNA from all samples to serve as a no-reverse transcription control. Nuclease-free water served as the no-template control. A cDNA pool was formed by combining equal quantities of cDNA from each sample and was used to generate a 5-point, 1:4 dilution series standard curve.

Primers (Table 1) were evaluated for each gene using the cDNA pool standard curve, and a single product was verified before sample analysis using the following protocol: 1 cycle at $95^{\circ} \mathrm{C}$ for $3 \mathrm{~min} ; 45$ cycles at $95^{\circ} \mathrm{C}$ for $5 \mathrm{~s}, 55^{\circ} \mathrm{C}$ for $5 \mathrm{~s}$, and a melt curve from $65^{\circ} \mathrm{C}$ to $95^{\circ} \mathrm{C}$, increasing in $0.5^{\circ} \mathrm{C}$ increments for $3 \mathrm{~s}$. Gene expression was determined for $C P T 1 A, G 6 P C, M T T P, P C, P C K 1$, and $P P A R A$. Samples were analyzed in triplicate using the following protocol: 1 cycle at $95^{\circ} \mathrm{C}$ for $3 \mathrm{~min}$ and 45 cycles at $95^{\circ} \mathrm{C}$ for $5 \mathrm{~s}, 55^{\circ} \mathrm{C}$ for $5 \mathrm{~s}$. Efficiencies between 90 and $110 \%$ based on the standard curve were used for analysis, and data were transformed using the Bio-Rad CFX Manager Software 3.1 (Bio-Rad Laboratories). Expression of genes of interest were normalized to the arithmetic mean of the expression of 2 reference genes within each sample: $\alpha$-1-microglobulin/bikunin precursor $(A M B P)$ and hydroxymethylbilane synthase $(H M B S)$. The use of the arithmetic mean of $A M B P$ and $H M B S$ for data normalization was verified by the lack of treatment effects on the threshold cycle and differences of threshold cycle values of $<1$ between treatments. Further interrogation of the stability of reference genes was done via NormFinder (Andersen et al., 2004), with arithmetic mean data confirmed as most stable $(M=0.02)$ compared with the geometric mean or either reference gene alone. Data are expressed as mRNA expression of each gene of interest.

Table 1. Primers used for analysis of gene expression in real-time quantitative PCR by functionality

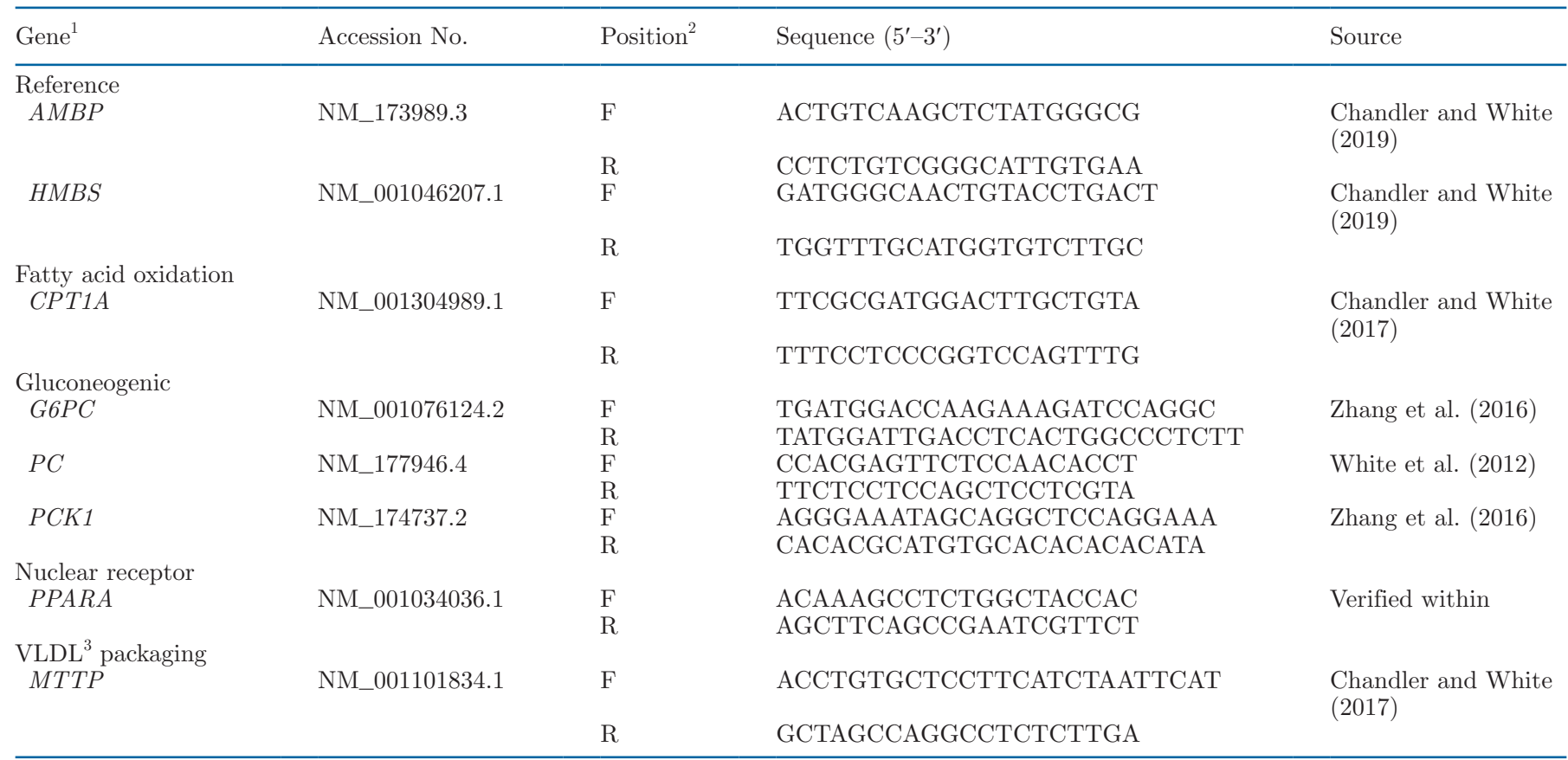

\footnotetext{
${ }^{1}$ Alpha-1-microglobulin bikunin precursor $(A M B P)$, hydroxymethylbilane synthase $(H M B S)$, carnitine palmitoyltransferase 1 A $(C P T 1 A)$ glucose-6-phosphatase $(G 6 P C)$, pyruvate carboxylase $(P C)$, cytosolic phosphoenolpyruvate carboxykinase $(P C K 1)$, peroxisome proliferatoractivated receptor $\alpha(P P A R A)$, and microsomal triglyceride transfer protein $(M T T P)$.

${ }^{2} \mathrm{~F}=$ forward; $\mathrm{R}=$ reverse.

${ }^{3}$ Very low density lipoprotein.
} 


\section{Statistical Analysis}

Production variables for the original cohort $(\mathrm{n}=93)$ were analyzed previously (Zenobi et al., 2018a); statistical analysis on DMI, BW, BCS, and DMI as \% of BW for the subset $(n=64)$ of the original cohort were reanalyzed to account for any statistical differences between the 2 groups. Blood metabolites (BHB, FA, glucose) and hepatic TG content analyzed previously at $-14,+7,+14$, and +21 DRTC (Zenobi et al., 2018a) were reanalyzed for the subset $(\mathrm{n}=64)$ of the original cohort. Data not presented in the results can be found in the companion paper.

Gene expression was analyzed at $-14,+7,+14$, and +21 DRTC. Data were analyzed using PROC MIXED of SAS 9.4 (SAS Institute Inc., Cary, NC). Analysis accounted for the fixed effects of DE, RPC, DRTC, and the random effect of cow within treatment. Two- and 3 -way interactions between DE, RPC, and DRTC were also analyzed. The REPEATED statement was used for repeated measures, and a power correlation covariance structure was used because biopsy time points were unequally spaced. Means were considered different when $P \leq 0.05$ and tended to differ if $0.05<P \leq 0.10$. Means were separated within significant 2 -way interactions with Tukey-Kramer studentized adjustments. Within significant 3-way interactions, the slice option was used to separate means within a specific DRTC. Results are reported as least squares means \pm standard error of the mean.

\section{RESULTS}

Complete results for the original cohort of cows (n $=93$ ) are presented in the companion paper (Zenobi et al., 2018a). Given that selection of the subset of cows for gene expression analysis was not completely random, relevant production variables and metabolites were analyzed for the subset of cows $(\mathrm{n}=64)$ and reported here in Supplemental Tables S1, S2, and S3 (https://doi.org/10.3168/jds.2020-18840) to confirm that the subset is similar to and representative of the original cohort.

\section{Effect of Dietary Treatment on Production Variables, Liver Health, and Blood Metabolites}

As was the case for the whole cohort reported in Zenobi et al. (2018a), there were no interactions of DE $\times$ RPC supplementation on production, liver, or blood variables measured. As reported previously (Zenobi et al., 2018a) for the whole cohort, prepartum DMI $(\mathrm{kg} / \mathrm{d}$ and \% of BW) and BW were not affected by DE in the subset $(P \geq 0.11$; Supplemental Table S1).
Postpartum DMI was greater $(P=0.05)$ in MNE than EXE, and an interaction of DE $\times$ DRTC $(P=0.08)$ tended to decrease DMI $(\mathrm{kg} / \mathrm{d}$ and $\%$ of BW) in EXE fed cows (Supplemental Table S2), similar to Zenobi et al. (2018a). Cows fed MNE had improved $(P=0.02)$ energy balance across the first 3 wk of lactation and tended to have improved $(P=0.07)$ energy balance across the first 15 wk of lactation (Supplemental Table S2). Dietary energy did not affect milk or milk component yields but cows fed MNE had decreased $(P=$ 0.01) milk fat percent (Supplemental Table S3). Glucose concentrations were unaffected $(P=0.69)$ by DE. Concentrations of BHB and liver TG $(\mu \mathrm{g} / \mu \mathrm{g}$ of DNA) were greater $(P \leq 0.03)$ in cows fed EXE than in cows fed MNE (Supplemental Table S2).

Supplementation of RPC had no effect on DMI $(\mathrm{kg} / \mathrm{d}$ and \% of BW; Supplemental Table S2) during the first 3 wk $(P \geq 0.11)$ nor up to 15 wk of lactation $(P \geq$ $0.25)$ or on BW $(P \geq 0.42)$ throughout the postpartum period (Zenobi et al., 2018a). Supplementation of RPC increased milk yield $(P=0.04)$, milk protein yield $(P$ $=0.04)$, and milk fat yield $(P=0.02)$, as reported in Supplemental Table S3. Supplementation of RPC did not alter $(P \geq 0.18)$ BHB, glucose, and circulating FA concentrations, or liver TG accumulation (Supplemental Table S2).

\section{Effect of Dietary Treatment and Interactions on Hepatic Gene Expression}

Hepatic expression of $C P T 1 A(P \geq 0.20)$ was not altered by $\mathrm{DE}, \mathrm{RPC}$, or the interaction of $\mathrm{DE} \times \mathrm{RPC}$ (Table 2; Figure 1). The treatment interaction altered $(P=0.001)$ G6PC, with reduced expression with RPC supplementation only in MNE cows (Figure 1). Expression of MTTP (Table 2) was not affected by DE $(P=$ $0.19)$ but was increased $(P=0.003)$ by RPC supplementation, with no treatment interaction detected $(P$ $=0.92)$. A dietary treatment interaction was detected for expression of $P C(P=0.02)$, although means were not separated by post hoc comparisons (Figure 1). Expression of $P C K 1$ was altered $(P=0.004)$ by the interaction of dietary treatment, with reduced expression with RPC supplementation only in EXE cows (Figure 1). The dietary treatment interaction also altered $(P$ $<0.0001)$ PPARA expression, with greater expression with RPC supplementation only in MNE cows (Figure 1).

\section{Effect of Dietary Treatment by Time Interactions on Hepatic Gene Expression}

The 3 -way interaction (Figure 2 ) of $\mathrm{DE} \times \mathrm{RPC} \times$ DRTC did not alter $(P=0.92)$ expression of MTTP; 


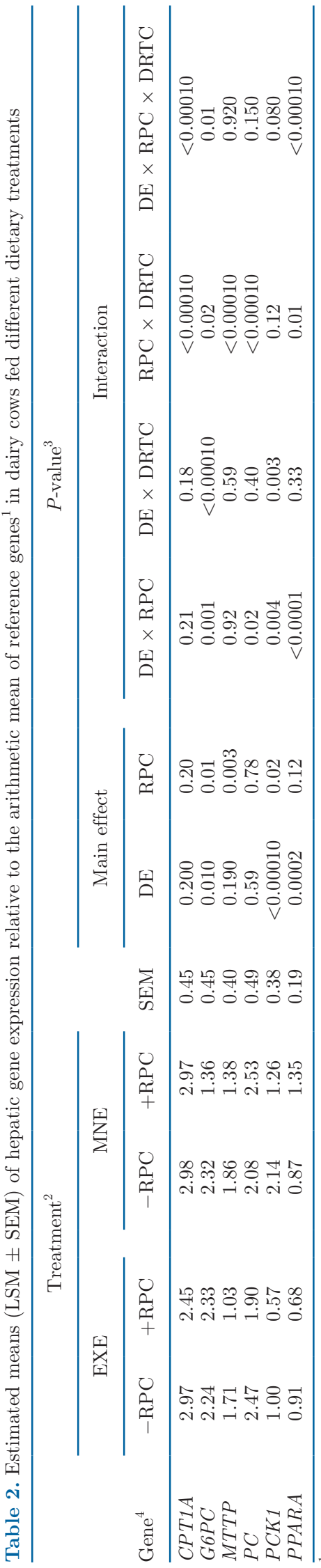

however, the RPC $\times$ DRTC interaction did influence $(P<0.0001)$ MTTP expression, with RPC supplementation decreasing MTTP expression at +21 DRTC compared with $-\mathrm{RPC}$ (Figure 2). Similarly, the 3-way interaction of DE $\times \mathrm{RPC} \times \mathrm{DRTC}$ did not alter $(P=$ $0.15)$ expression of $P C$, but there was an interaction of $\mathrm{RPC} \times \operatorname{DRTC}(P<0.0001)$.

The 3 -way interaction between $\mathrm{DE} \times \mathrm{RPC} \times \mathrm{DRTC}$ (Figure 2) affected expression of $C P T 1 A(P<0.0001)$, G6PC $(P=0.01)$, and PPARA $(P<0.0001)$ and tended to affect expression of PCK1 $(P=0.08)$. Cows fed MNE+RPC had greater $(P=0.04)$ expression of CPT1A compared with MNE-RPC cows at +7 DRTC. At +21 DRTC, expression of CPT1A was decreased $(P=0.01)$ in cows fed MNE $+\mathrm{RPC}$ compared with $\mathrm{EXE}+\mathrm{RPC}$ cows and MNE$-\mathrm{RPC}$ cows $(P<0.0001)$. Expression of $G 6 P C$ was increased $(P<0.0001)$ at +14 DRTC in EXE-RPC cows compared with MNE+RPC cows and tended to be increased $(P=0.08)$ at +21 DRTC in EXE-RPC cows compared with MNE+RPC cows. Additionally, G6PC expression was greater $(P$ $\leq 0.03)$ in $\mathrm{EXE}+\mathrm{RPC}$ cows and MNE-RPC cows compared with MNE $+\mathrm{RPC}$ cows at +21 DRTC. At +7 DRTC, expression of PPARA was decreased $(P=$ $0.01)$ in EXE-RPC cows compared with $\mathrm{MNE}+\mathrm{RPC}$ cows. Expression of PPARA tended to be greater $(P=$ $0.08)$ in $\mathrm{MNE}+\mathrm{RPC}$ cows compared with $\mathrm{EXE}+\mathrm{RPC}$ cows at +14 DRTC, and expression remained greater in $\mathrm{MNE}+\mathrm{RPC}$ cows at $+21 \mathrm{DRTC}(P=0.0001)$ compared with $\mathrm{EXE}+\mathrm{RPC}$ cows.

\section{DISCUSSION}

Controlling prepartum energy intake and supplementing RPC during the periparturient period are 2 strategies to optimize hepatic metabolic function and prevent hepatic lipid accumulation. Despite our understanding of the effects of these nutritional strategies, it was unclear if there was potential for an additive benefit of the 2 strategies on production and health. Production responses and health outcomes of periparturient cows to these treatments in a factorial design were examined thoroughly in a companion paper (Zenobi et al., 2018a) along with resulting immune responses (Zenobi et al., 2020). Within the companion paper (Zenobi et al., 2018a), prepartum EXE (140\% of energy requirement during the dry period) did not alter milk production postpartum but did result in greater concentrations of plasma FA and BHB, as well as greater liver TG. Supplementation of RPC for approximately $3 \mathrm{wk}$ before and $3 \mathrm{wk}$ after parturition tended to increase milk production and ECM over the first 15 wk postpartum without altering DMI, plasma FA, BHB, or liver TG concentrations. 
Interestingly, there were no interactions between DE or RPC treatments on production effects, supporting that the effects of RPC supplementation are independent of prepartum DE. The lack of interaction between RPC and DE may suggest that there are independent mechanisms of action for both these nutritional strategies; therefore, expression of hepatic genes involved in gluconeogenesis, FA oxidation, and lipid metabolism were examined in a subset of cows. Given that the selection of the subset of cows $(n=64)$ for gene expression analysis was not completely random, analysis of preand postpartum BW and DMI, as well as 15 wk milk production and components, plasma metabolites, and liver TG (Supplemental Tables S1, S2, and S3; https:/ /doi.org/10.3168/jds.2020-18840) was repeated on the subset of cows. Responses to DE and RPC supplementation were similar between the subset and the original cohort of cows; therefore, all results and discussion in the companion paper (Zenobi et al., 2018a) are relevant to the subset of cows used to determine the effect of treatment on hepatic gene expression and will not be extensively discussed here, although some relevant results will be briefly highlighted. Additionally, given that liver samples were collected within the peripartum period ( -14 to +21 DRTC), milk production and components and blood metabolites for this period (0 to 3 wk postpartum) were analyzed and presented for reference (Supplemental Tables S2 and S3).

Altering prepartum DE did not affect $P C$ or $P C K 1$ (Khan et al., 2014) and, although RPC supplementation did not alter expression of $P C K 1$ across the periparturient period, it did lessen the increase in $P C$ at parturition (Goselink et al., 2013). In the current study, RPC supplementation resulted in lower PCK1 expression only in EXE cows. Although treatment means could not be separated for the interaction of $\mathrm{DE} \times$ RPC supplementation on $P C$, a similar pattern is present. The source of dietary interaction on these genes is not apparent. Supplementation of choline chloride in primary hepatocytes increased gene expression of $P C K 1$ and $P C$ in the presence, but not absence, of 1 mM FA (Chandler and White, 2019); however, concen-

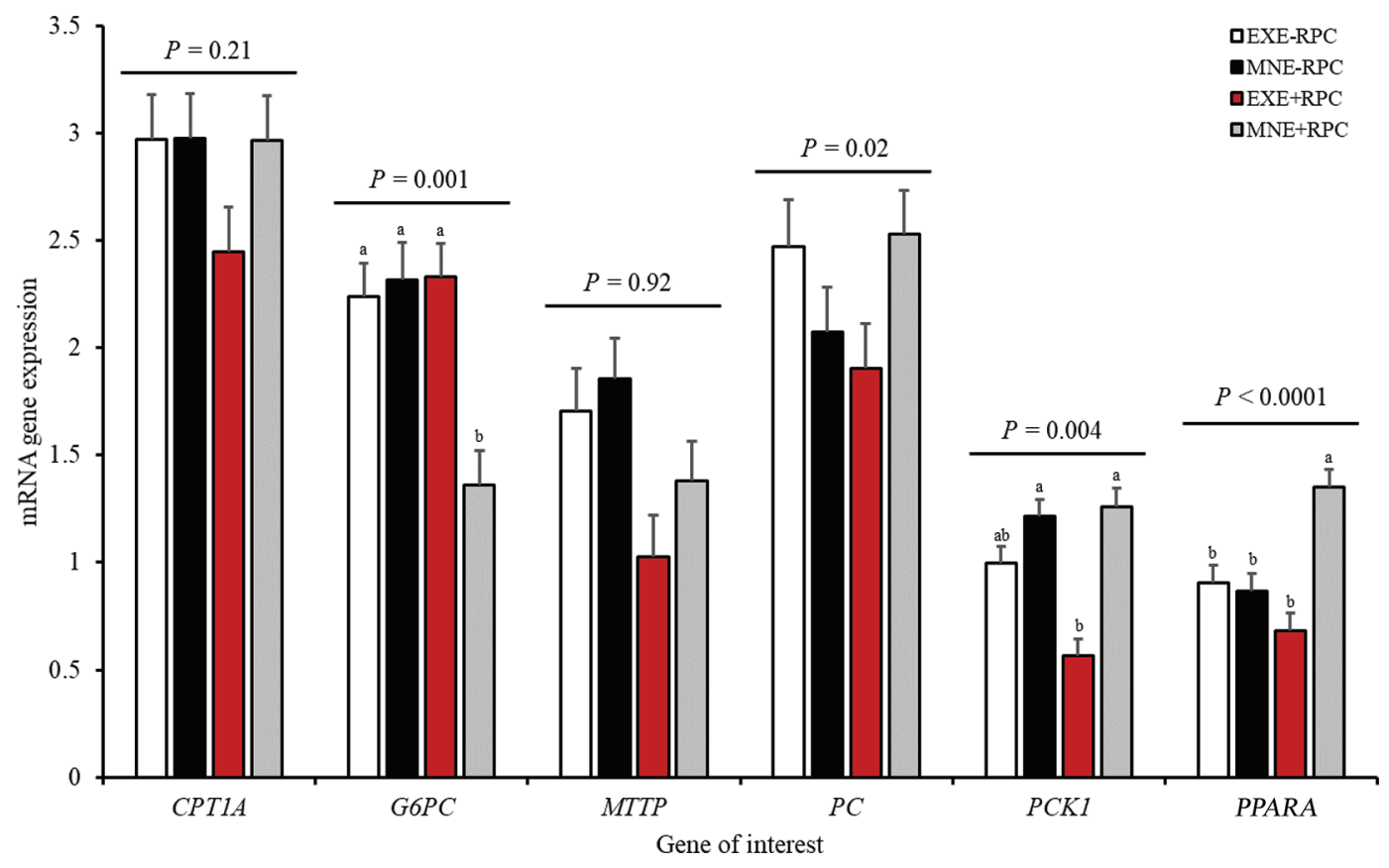

Figure 1. Separated means (LSM \pm SEM) of hepatic gene expression of supplementation of dietary energy (DE) by rumen-protected choline $(\mathrm{RPC} ; \mathrm{DE} \times \mathrm{RPC})$ of carnitine palmitoyltransferase $1 \mathrm{~A}(C P T 1 A)$, glucose-6-phosphatase $($ G6PC), microsomal triglyceride transfer protein $(M T T P)$, pyruvate carboxylase $(P C)$, cytosolic phosphoenolpyruvate carboxykinase $(P C K 1)$, and peroxisome proliferator-activated receptor a $(P P A R A)$ normalized to the arithmetic mean of the reference genes ( $\alpha$-1-microglobulin bikunin precursor and hydroxymethylbilane synthase) in cows fed excess energy and no RPC (EXE-RPC; open bars), maintenance energy and no RPC (MNE-RPC; closed bars), excess energy and RPC (EXE+RPC; red bars), and maintenance energy and RPC (MNE+RPC; gray bars). Treatments: EXE-RPC, excess energy (1.63 Mcal of $\mathrm{NE}_{\mathrm{L}} / \mathrm{kg}$ of $\left.\mathrm{DM}\right)$ and no RPC; MNE-RPC, maintenance energy (1.40 Mcal of $\mathrm{NE}_{\mathrm{L}} / \mathrm{kg}$ of DM) and no RPC; EXE+RPC, excess energy (1.63 Mcal of $\mathrm{NE}_{\mathrm{L}} / \mathrm{kg}$ of $\mathrm{DM}$ ) and a top-dress of $\mathrm{RPC}-21$ to $+21 \mathrm{~d}$ relative to calving at $60 \mathrm{~g} / \mathrm{d}$; and MNE+RPC, maintenance energy (1.40 Mcal of $\mathrm{NE}_{\mathrm{L}} / \mathrm{kg}$ of $\mathrm{DM}$ ) and a top-dress of $\mathrm{RPC}-21$ to $+21 \mathrm{~d}$ relative to calving at $60 \mathrm{~g} / \mathrm{d}$. $P$-values reported are for the $\mathrm{DE} \times \mathrm{RPC}$ interaction. Differences between means are denoted by letters $(\mathrm{a}, \mathrm{b})$. Treatment means for expression of $P C(P=0.02)$ could not be separated. Dietary interaction was significant for expression of $G 6 P C(P=0.001), P C K 1(P=0.004)$, and PPARA $(P<0.0001)$ but not for expression of $C P T 1 A$ $(P=0.21)$ and $\operatorname{MTTP}(P=0.92)$. 

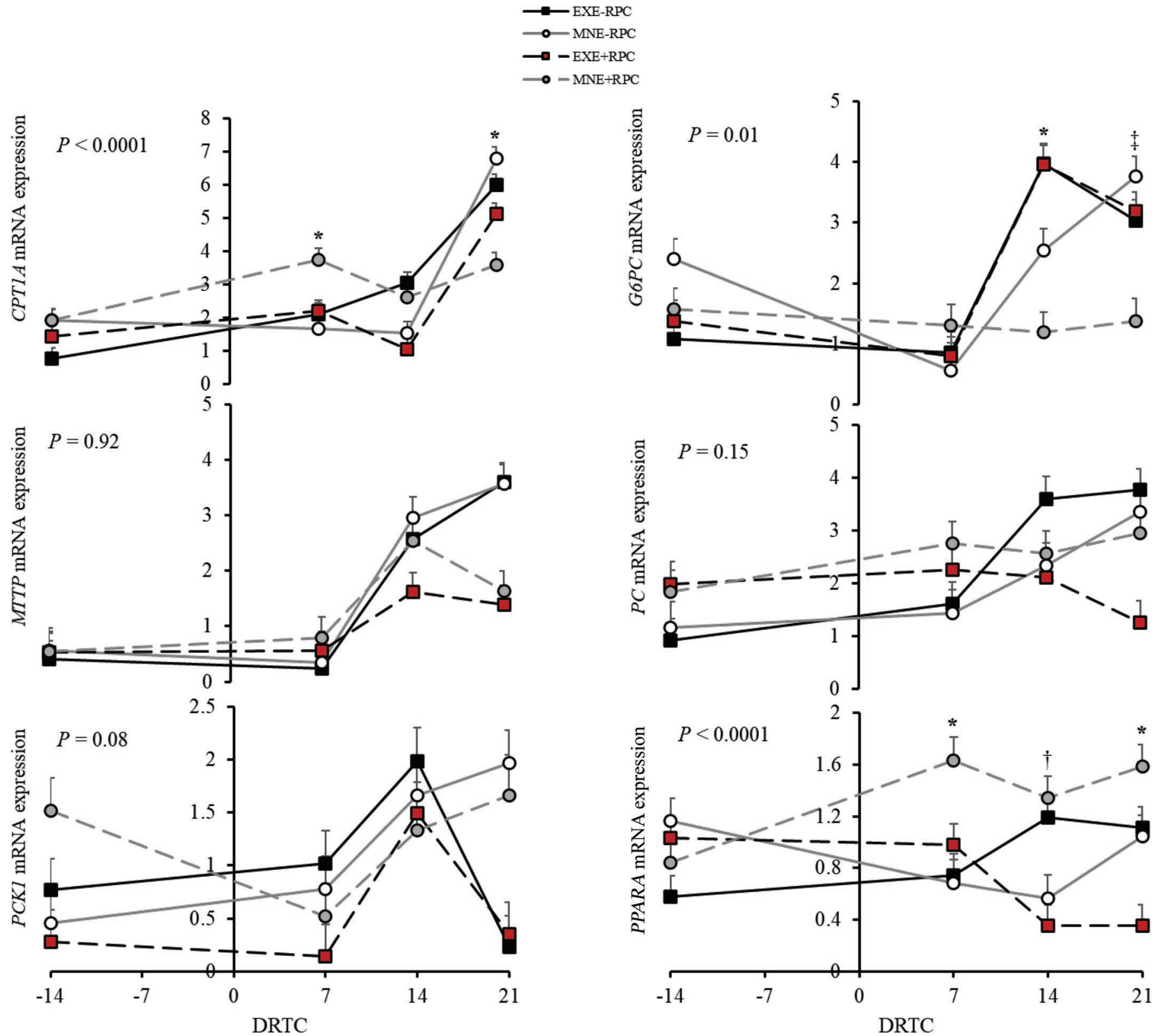

Figure 2. Separated means (LSM \pm SEM) of hepatic gene expression of supplementation of dietary energy (DE) by rumen-protected choline $(\mathrm{RPC})$ by days relative to calving (DRTC; DE $\times \mathrm{RPC} \times \mathrm{DRTC})$ of carnitine palmitoyltransferase $1 \mathrm{~A}(C P T 1 A)$, glucose-6-phosphatase $(G 6 P C)$, microsomal triglyceride transfer protein $(M T T P)$, pyruvate carboxylase $(P C)$, cytosolic phosphoenolpyruvate carboxykinase $(P C K 1)$, and peroxisome proliferator-activated receptor $\alpha(P P A R A)$ normalized to the arithmetic mean of the reference genes $(\alpha-1$-microglobulin bikunin precursor and hydroxymethylbilane synthase) in cows fed excess energy and no RPC (EXE-RPC; closed squares, black solid line), maintenance energy and no RPC (MNE-RPC; open circles, gray solid line), excess energy and RPC (EXE+RPC; red squares, black dashed line), and maintenance energy and RPC (MNE+RPC; gray circles, gray dashed line). Treatments: EXE-RPC, excess energy $(1.63 \mathrm{Mcal}$ of NE $/ \mathrm{kg}$ of $\mathrm{DM})$ and no RPC; MNE-RPC, maintenance energy (1.40 Mcal of $\mathrm{NE}_{\mathrm{L}} / \mathrm{kg}$ of DM) and no RPC; EXE+RPC, excess energy (1.63 Mcal of $\mathrm{NE}_{\mathrm{L}} / \mathrm{kg}$ of $\mathrm{DM})$ and a top-dress of RPC -21 to $+21 \mathrm{~d}$ relative to calving at $60 \mathrm{~g} / \mathrm{d}$; and $\mathrm{MNE}+\mathrm{RPC}$, maintenance energy $(1.40 \mathrm{Mcal}$ of $\mathrm{NE} / \mathrm{kg}$ of $\mathrm{DM})$ and a top-dress of RPC -21 to +21 d relative to calving at $60 \mathrm{~g} / \mathrm{d}$. $P$-values reported are for the DE $\times$ RPC $\times$ DRTC interaction. Expression of CPT1A $(P<0.0001), G 6 P C(P=0.01)$, and PPARA $(P=0.33)$ changed with the 3 -way interaction. Expression of $P C K 1(P=0.08)$ tended to change with the 3 -way interaction. Expression of $\operatorname{MTTP}(P=0.92)$ and $P C(P=0.15)$ did not change with the 3 -way interaction. Tendencies within DRTC are denoted with a dagger $(0.05<P \leq 0.10 ; \dagger)$, significance within DRTC is denoted with an asterisk $(P \leq 0.05 ; *)$, and DRTC that have both a tendency and significant effect between different treatment groups are denoted by a double dagger $(P \leq 0.10 ; \ddagger)$. 
tration of blood FA was not different across treatments in the current study. Given the role of $P C K 1$ and $P C$ in influencing anaplerosis and cataplerosis of the tricarboxylic acid (TCA) cycle, this interaction could be reflective of altered energetic state within hepatocytes of cows fed EXE with RPC.

Plasma glucose concentrations and milk lactose output were unchanged by DE and RPC treatments; however, there was an interaction of dietary treatments to influence $G 6 P C$, the final enzyme in the gluconeogenic pathway. In contrast to the effect of dietary interaction on $P C$ and $P C K 1, G 6 P C$ expression was decreased with RPC supplementation only when the MNE diet was fed (Figure 1), especially at +14 and +21 DRTC (Figure 2). The biological impact of altering G6PC expression as an indicator of hepatic glucose production is not completely clear because expression is sometimes (Cedeño et al., 2008; Caputo Oliveira et al., 2020) but not always (White et al., 2016) changed during the periparturient period.

Both energy requirements and shared precursors closely link gluconeogenesis and FA oxidation (White, 2020). Regulation of many genes involved in FA oxidation is coordinated by transcription factors including peroxisome proliferator-activated receptor $\alpha(\operatorname{PPAR} \alpha)$, which coordinates regulation of genes involved in oxidation via the tricarboxylic acid cycle, ketogenesis, and gluconeogenesis in cattle (Goselink et al., 2013). Expression of PPARA was not changed by altering prepartum DE (Khan et al., 2014; Huang et al., 2019). Similarly, expression of PPARA was unchanged by RPC supplementation (Goselink et al., 2013). In the current study, supplementation of RPC increased expression of PPARA when MNE diets were fed (Figure 1), specifically from +7 to +21 DRTC (Figure 2). Expression of PPARA can be activated by FA (Thering et al., 2009; Ruby et al., 2010; Bionaz et al., 2013) and although $\mathrm{MNE}+\mathrm{RPC}$ cows tended to have greater plasma FA concentrations within the full cohort (Zenobi et al., 2018a), this was not observed in the subset used for gene expression data (Supplemental Table S2). Expression of $G 6 P C$ is also modulated by $P P A R A$, specifically upregulating expression during fasting in mice; $P P A R A$ knockout mice lack this response (Im et al., 2011). Although less explored in ruminants, a similar relationship between PPAR $\alpha$ and G6PC has been proposed (Bionaz et al., 2013). Given that the same treatment combination that increases PPAR $\alpha$ decreased G6PC, it is possible that the G6PC expression was inhibited by PPAR $\alpha$, although that cannot be directly determined within this experimental design. Conversely, PC expression may be upregulated by $\operatorname{PPAR} \alpha$ (White et al., 2011), a pattern consistent with the current study. The role of PPAR $\alpha$ to modulate pathways could be an underlying mechanism of the treatment interactions observed within this study, especially considering the change in energy status across the transition to lactation period and the pattern of treatment separation generally observed at +21 DRTC for several genes quantified within this study. The interactions reported herein are intriguing and should be further explored considering the potential downstream impact of PPARA regulation on FA and glucose metabolism.

Hepatic carnitine palmitoyltransferase 1A (CPT1A) transfers FA into the mitochondria (Kerner and Hoppel, 2000; Xu et al., 2011) and is a known target of PPARA across species (Louet et al., 2001; van Dorland et al., 2009; Rakhshandehroo et al., 2010). Increased CPT1A expression is associated with an increased rate of oxidation, decreased accumulation of TG (Stefanovic-Racic et al., 2008), and decreased lipid-related metabolic disorders in dairy cattle (Drackley, 1999). Excess prepartum dietary energy has previously been shown to increase (Khan et al., 2014) or not alter (Huang et al., 2019) CPT1A expression. Despite lower BHB and liver TG (ug/ug of DNA) in cows fed MNE (Supplemental Table S2), expression of CPT1A was not changed by $\mathrm{DE}, \mathrm{RPC}$, or the interaction (Table 2). This is consistent with previous studies where CPT1A expression was not altered by choline chloride supplementation in vitro (Chandler and White, 2017) or RPC supplementation in vivo (Goselink et al., 2013).

Representing a downstream step in cellular lipid metabolism, MTTP is involved in very low density lipoproteins (VLDL) packaging (Gruffat-Mouty et al., 1999; Bernabucci et al., 2004; Goselink et al., 2013). Expression of MTTP was increased immediately after calving with no relationship between MTTP expression and plasma FA concentration or liver TG content (Bremmer et al., 2000). In the current study, the dietary treatment interaction did not alter MTTP expression; however, expression was affected by RPC $\times$ DRTC (Table 2). Likewise, RPC supplementation increased MTTP expression in vivo (Goselink et al., 2013). Despite these observations, in vitro supplementation of choline chloride to bovine neonatal primary hepatocytes decreased MTTP expression, even when VLDL export was increased (Chandler and White, 2017). Interestingly, there was no $\mathrm{DE} \times \mathrm{RPC}$ nor $\mathrm{DE} \times \mathrm{RPC}$ $\times$ DRTC effect on MTTP, even though decreased liver lipid content was observed in MNE cows. Considered with other findings, it is not likely that MTTP is a rate-limiting step for VLDL export.

\section{CONCLUSIONS}

Although the effect of controlling prepartum DE and supplementing RPC during the periparturient period 
did not demonstrate any interactions in postpartum production or health variables, these nutritional strategies interacted to influence expression of $G 6 P C, P C$, $P C K 1$, and PPARA. Overall, these data highlight that, despite independent effects of nutritional interventions on production responses, periparturient nutritional strategies may not always function through separate hepatic pathways.

\section{ACKNOWLEDGMENTS}

The authors thank collaborators and farm personnel at the University of Florida (Gainesville, FL) for collection of liver biopsy samples and collaboration throughout the study. This research was partially supported through graduate student support from the University of Milan, Italy through the Graduated Student Support program and by Balchem Corporation (New Hampton, NY). The authors have not stated any conflicts of interest.

\section{REFERENCES}

Andersen, C. L., J. L. Jensen, and T. F. Ørntoft. 2004. Normalization of real-time quantitative reverse transcription-PCR data: A model-based variance estimation approach to identify genes suited for normalization, applied to bladder and colon cancer data sets. Cancer Res. 64:5245-5250. https://doi.org/10.1158/0008-5472 .CAN-04-0496.

Arshad, U., M. G. Zenobi, C. R. Staples, and J. E. P. Santos. 2020. Meta-analysis of the effects of supplemental rumen-protected choline during the transition period on performance and health of parous dairy cows. J. Dairy Sci. 103:282-300. https://doi.org/10 $.3168 /$ jds.2019-16842.

Bernabucci, U., B. Ronchi, L. Basiricò, D. Pirazzi, F. Rueca, N. Lacetera, and A. Nardone. 2004. Abundance of mRNA of apolipoprotein B 100, apolipoprotein E, and microsomal triglyceride transfer protein in liver from periparturient dairy cows. J. Dairy Sci. 87:2881-2888. https://doi.org/10.3168/jds.S0022-0302(04)73418 $-9$.

Bionaz, M., S. Chen, M. J. Khan, and J. J. Loor. 2013. Functional role of PPARs in ruminants: Potential targets for fine-tuning metabolism during growth and lactation. PPAR Res. 2013:684159684187. https://doi.org/10.1155/2013/684159.

Block, S. S., W. R. Butler, R. A. Ehrhardt, A. W. Bell, M. E. van Amburgh, and Y. R. Boisclair. 2001. Decreased concentration of plasma leptin in periparturient dairy cows is caused by negative energy balance. J. Endocrinol. 171:339-348. https://doi.org/10 $.1677 /$ joe.0.1710339.

Bremmer, D. R., S. J. Bertics, S. A. Besong, and R. R. Grummer. 2000. Changes in hepatic microsomal triglyceride transfer protein and triglyceride in periparturient dairy cattle. J. Dairy Sci. 83:2252-2260. https://doi.org/10.3168/jds.S0022-0302(00)75109 $-5$.

Caputo Oliveira, R., S. J. Erb, R. S. Pralle, H. T. Holdorf, C. R. Seely, and H. M. White. 2020. Postpartum fermented ammoniated condensed whey supplementation altered nutrient partitioning to support hepatic metabolism. J. Dairy Sci. 103:7055-7067. https:// doi.org/10.3168/jds.2019-17790.

Cedeño, E. M., S. L. Koser, and S. S. Donkin. 2008. Plasma and tissue concentrations of glucose, acetate, propionate, lactate, and hydroxybutyrate in calves subjected to conventional and accelerated milk replacer programs. J. Dairy Sci. 91(E. Suppl. 1):424. (Abstr.)
Chandler, T. L., and H. M. White. 2017. Choline and methionine differentially alter methyl carbon metabolism in bovine neonatal hepatocytes. PLoS ONE 12:e171080. https://doi.org/10.1371/ journal.pone.0171080.

Chandler, T. L., and H. M. White. 2019. Glucose metabolism is differentially altered by choline and methionine in bovine neonatal hepatocytes. PLoS One 14:e217160. https://doi.org/10.1371/ journal.pone.0217160.

Chomczynski, P. 1993. A reagent for the single-step simultaneous isolation of RNA, DNA, and proteins from cell and tissue samples. Biotechniques 15:532-534., 536-537.

Contreras, G. A., C. Strieder-Barboza, J. de Souza, J. Gandy, V. Mavangira, A. L. Lock, and L. M. Sordillo. 2017. Periparturient lipolysis and oxylipid biosynthesis in bovine adipose tissues. PLoS One 12:e0188621. https://doi.org/10.1371/journal.pone.0188621.

Dole, V. P. 1956. A relation between non-esterified fatty acids in plasma and the metabolism of glucose. J. Clin. Invest. 35:150-154. https://doi.org/10.1172/JCI103259.

Drackley, J. K. 1999. Biology of dairy cows during the transition period: The final frontier? J. Dairy Sci. 82:2259-2273. https://doi .org/10.3168/jds.S0022-0302(99)75474-3.

Drackley, J. K., T. R. Overton, and G. N. Douglas. 2001. Adaptations of glucose and long-chain fatty acid metabolism in liver of dairy cows during the periparturient period. J. Dairy Sci. 84(E Suppl.):100-112. https://doi.org/10.3168/jds.S0022-0302(01)70204-4.

Drackley, J. K., R. L. Wallace, D. Graugnard, J. Vasquez, B. F. Richards, and J. J. Loor. 2014. Visceral adipose tissue mass in nonlactating dairy cows fed diets differing in energy density. J. Dairy Sci. 97:3420-3430. https://doi.org/10.3168/jds.2014-8014.

Gordon, R. S. Jr., and A. Cherkes. 1956. Unesterified fatty acid in human blood plasma. J. Clin. Invest. 35:206-212. https://doi.org/ 10.1172/JCI103265.

Goselink, R. M. A., J. van Baal, H. C. C. Widjaja, R. A. Dekker, R. L. Zom, M. J. De Veth, and A. M. van Vuuren. 2013. Effect of rumenprotected choline supplementation on liver and adipose gene expression during the transition period in dairy cattle. J. Dairy Sci. 96:1102-1116. https://doi.org/10.3168/jds.2012-5396.

Graugnard, D. E., K. M. Moyes, E. Trevisi, M. J. Khan, D. Keisler, J. K. Drackley, G. Bertoni, and J. J. Loor. 2013. Liver lipid content and inflammometabolic indices in peripartal dairy cows are altered in response to prepartal energy intake and postpartal intramammary inflammatory challenge. J. Dairy Sci. 96:918-935. https:// doi.org/10.3168/jds.2012-5676.

Gruffat-Mouty, D., B. Graulet, D. Durand, M. E. Samson-Bouma, and D. Bauchart. 1999. Apolipoprotein B production and very low density lipoprotein secretion by calf liver slices. J. Biochem. 126:188-193. https://doi.org/10.1093/oxfordjournals.jbchem .a022421.

Grummer, R. R. 1993. Etiology of lipid-related metabolic disorders in periparturient dairy cows. J. Dairy Sci. 76:3882-3896. https://doi .org/10.3168/jds.S0022-0302(93)77729-2.

Grummer, R. R. 1995. Impact of changes in organic nutrient metabolism on feeding the transition dairy cow. J. Anim. Sci. 73:28202833. https://doi.org/10.2527/1995.7392820x.

Grummer, R. R., D. G. Mashek, and A. Hayirli. 2004. Dry matter intake and energy balance in the transition period. Vet. Clin. North Am. Food Anim. Pract. 20:447-470. https://doi.org/10.1016/j .cvfa.2004.06.013.

Huang, W., L. Wang, S. Li, and Z. Cao. 2019. Effect of reduced energy density of close-up diets on metabolites, lipolysis and gluconeogenesis in Holstein cows. Asian-Australas. J. Anim. Sci. 32:648-656. https://doi.org/10.5713/ajas.18.0624.

Im, S. S., M. Kim, S. Kwon, T. Kim, J. Bae, H. Kim, K. Kim, G. Oh, and Y. Ahn. 2011. Peroxisome proliferator-activated receptor $\alpha$ is responsible for the up-regulation of hepatic glucose-6-phosphatase gene expression in fasting and $\mathrm{db} / \mathrm{db}$ mice. J. Biol. Chem. 286:1157-1164. https://doi.org/10.1074/jbc.M110.157875.

Janovick, N. A., Y. R. Boisclair, and J. K. Drackley. 2011. Prepartum dietary energy intake affects metabolism and health during the periparturient period in primiparous and multiparous Holstein 
cows. J. Dairy Sci. 94:1385-1400. https://doi.org/10.3168/jds.2010 $-3303$.

Kerner, J., and C. Hoppel. 2000. Fatty acid import into mitochondria. Biochim. Biophys. Acta 1486:1-17. https://doi.org/10.1016/S1388 -1981(00)00044-5.

Khan, M. J., C. B. Jacometo, D. E. Graugnard, M. N. Corrêa, E. Schmitt, F. Cardoso, and J. J. Loor. 2014. Overfeeding dairy cattle during late-pregnancy alters hepatic PPAR $\alpha$-regulated pathways including hepatokines: Impact on metabolism and peripheral insulin sensitivity. Gene Regul. Syst. Bio. 8:97-111. https://doi.org/10 .4137 /GRSB.S14116.

Louet, J. F., F. Chatelain, J. F. Decaux, E. A. Park, C. Kohl, T. Pineau, J. Girard, and J. P. Pegorier. 2001. Long-chain fatty acids regulate liver carnitine palmitoyltransferase I gene (L-CPT I) expression through a peroxisome-proliferator-activated receptor $\alpha$ (PPAR $\alpha$ )-independent pathway. Biochem. J. 354:189-197. https:/ /doi.org/10.1042/bj3540189.

Mann, S., F. L. Yepes, T. R. Overton, J. J. Wakshlag, A. L. Lock, C. M. Ryan, and D. V. Nydam. 2015. Dry period plane of energy: Effects on feed intake, energy balance, milk production, and composition in transition dairy cows. J. Dairy Sci. 98:3366-3382. https:/ /doi.org/10.3168/jds.2014-9024.

McFadden, J. W., C. L. Girard, S. Tao, Z. Zheng, J. K. Bernard, M. Duplessis, and H. M. White. 2020. Symposium review: One-carbon metabolism and methyl donor nutrition in the dairy cow. J. Dairy Sci. 103:5668-5683. https://doi.org/10.3168/jds.2019-17319.

Overton, T. R., and M. S. Piepenbrink. 1999. Liver metabolism and the transition cow. Page 10 in Proc. 1999 Cornell Nutr. Conf. Feed Manufacturers. Cornell University, Ithaca, NY.

Rakhshandehroo, M., B. Knoch, M. Müller, and S. Kersten. 2010. Peroxisome proliferator-activated receptor alpha target genes. PPAR Res. 2020:612089. https://doi.org/10.1155/2010/612089.

Ruby, M. A., B. Goldenson, G. Orasanu, T. P. Johnston, J. Plutzky, and R. M. Krauss. 2010. VLDL hydrolysis by LPL activates PPAR- $\alpha$ through generation of unbound fatty acids. J. Lipid Res. 51:2275-2281. https://doi.org/10.1194/jlr.M005561.

Stefanovic-Racic, M., G. Perdomo, B. S. Mantell, I. J. Sipula, N. F. Brown, and R. M. O'Doherty. 2008. A moderate increase in carnitine palmitoyltransferase 1a activity is sufficient to substantially reduce hepatic triglyceride levels. Am. J. Physiol. Endocrinol. Metab. 294:E969-977. https://doi.org/10.1152/ajpendo.00497 2007.

Thering, B. J., M. Bionaz, and J. J. Loor. 2009. Long-chain fatty acid effects on peroxisome proliferator-activated receptor- $\alpha$-regulated genes in Madin-Darby bovine kidney cells: Optimization of culture conditions using palmitate. J. Dairy Sci. 92:2027-2037. https://doi .org/10.3168/jds.2008-1749.

van Dorland, H. A., S. Richter, I. Morel, M. G. Doherr, N. Castro, and R. M. Bruckmaier. 2009. Variation in hepatic regulation of metabolism during the dry period and in early lactation in dairy cows. J. Dairy Sci. 92:1924-1940. https://doi.org/10.3168/jds.2008-1454.

White, H. M. 2015. The role of TCA cycle anaplerosis in ketosis and fatty liver in periparturient dairy cows. Animals (Basel) 5:793-802. https://doi.org/10.3390/ani5030384.
White, H. M. 2020. ADSA Foundation Scholar Award: Influencing hepatic metabolism: Can nutrient partitioning be modulated to optimize metabolic health in the transition dairy cow? J. Dairy Sci. 103:6741-6750. https://doi.org/10.3168/jds.2019-18119.

White, H. M., E. R. Carvalho, S. L. Koser, N. S. Schmelz-Roberts, L. M. Pezzanite, A. C. Slabaugh, P. H. Doane, and S. S. Donkin. 2016. Short communication: Regulation of hepatic gluconeogenic enzymes by dietary glycerol in transition dairy cows. J. Dairy Sci. 99:812-817. https://doi.org/10.3168/jds.2015-9953.

White, H. M., S. L. Koser, and S. S. Donkin. 2011. Differential regulation of bovine pyruvate carboxylase promoters by fatty acids and peroxisome proliferator-activated receptor- $\alpha$ agonist. J. Dairy Sci. 94:3428-3436. https://doi.org/10.3168/jds.2011-3960.

White, H. M., S. L. Koser, and S. S. Donkin. 2012. Gluconeogenic enzymes are differentially regulated by fatty acid cocktails in MadinDarby bovine kidney cells. J. Dairy Sci. 95:1249-1256. https://doi .org/10.3168/jds.2011-4644.

Xu, C., Z. Wang, R. Zhang, H. Zhang, S. Fu, and C. Xia. 2011. Effect of NEFA and glucose levels on CPT-I mRNA expression and translocation in cultured bovine hepatocytes. J. Vet. Med. Sci. 73:97-101. https://doi.org/10.1292/jvms.10-0164.

Zenobi, M. G., R. Gardinal, J. E. Zuniga, A. L. G. Dias, C. D. Nelson, J. P. Driver, B. A. Barton, J. E. P. Santos, and C. R. Staples. 2018a. Effects of supplementation with ruminally protected choline on performance of multiparous Holstein cows did not depend upon prepartum caloric intake. J. Dairy Sci. 101:1088-1110. https: //doi.org/10.3168/jds.2017-13327.

Zenobi, M.G., R. Gardinal, J.E. Zuniga, L.K. Mamedova, J.P. Driver, B.A. Barton, J.E.P. Santos, C.R. Staples, and C.D. Nelson. 2020 Effect of prepartum energy intake and supplementation with ruminally protected choline on innate and adaptive immunity of multiparous Holstein cows. J. Dairy Sci. 103:2200-2216. https://doi .org/10.3168/jds.2019-17378.

Zenobi, M. G., T. L. Scheffler, J. E. Zuniga, M. B. Poindexter, S. R. Campagna, H. F. Castro Gonzalez, A. T. Farmer, B. A. Barton, J. E. P. Santos, and C. R. Staples. 2018b. Feeding increasing amounts of ruminally protected choline decreased fatty liver in nonlactating, pregnant Holstein cows in negative energy status. J. Dairy Sci. 101:5902-5923. https://doi.org/10.3168/jds.2017-13973.

Zhang, Q., S. L. Koser, and S. S. Donkin. 2016. Propionate induces mRNA expression of gluconeogenic genes in bovine calf hepatocytes. J. Dairy Sci. 99:3908-3915. https://doi.org/10.3168/jds .2015-10312.

\section{ORCIDS}

V. Caprarulo (1) https://orcid.org/0000-0003-3691-4608

S. J. Erb ๑ https://orcid.org/0000-0001-8259-4866

T. L. Chandler @ https://orcid.org/0000-0001-6299-9436

C. R. Staples $\odot$ https://orcid.org/0000-0002-0237-946X

H. M. White $\odot$ https://orcid.org/0000-0001-5449-2811 